\title{
PERENNIAL RYEGRASS CULTIVARS
}

\author{
J. A. Lancashire ${ }^{1}$, A. J. Harris', C. S. Armstrong' \\ and D. L. RYAN'
}

\section{Grasslands Division, DSIR, Palmerston North' and Gore ${ }^{2}$}

\author{
Abstract
}

In the period $1973-77,71 \%$ of pasture grasses certified in New Zealand were perennial ryegrasses. Data from one of the major seed merchants showed that during 1977-8 Ruanui comprised over $70 \%$ of the retail sales of perennial ryegrass cultivars, while Nui $(17 \%)$ and Ariki (10\%) were also important.

Comparative production data between the New Zealand bred cultivars, some overseas cultivars and some uncertified local populations are presented. Overseas cultivars are generally inferior to New Zealand cultivars but some local populations are very promising in a number of environments.

The newer cultivars Nui and Ariki often show a greater yield response to longer intervals between defoliations and increased nitrogen supply than Ruanui.

\section{INTRODUCTION}

RYGRASSES, particularly perennials, are the most important pasture grasses sown in New Zealand. Their ability to support grazing animals over a wide range of climatic, soil fertility and grazing variables is well recognized. The seed requirement for the area resown each year to pasture and lucerne, which was 294000 ha in 1972-3 (Statistics Dept., 1976), provides a basis for an important industry. The importance of perennial ryegrasses in this industry is shown in Table 1.

TABLE 1: MEAN ANNUAL QUANTITY OF PASTURE GRASSES CERTIFIED IN NZ*

(Machine-dressed seed, 1973-77)

\begin{tabular}{llllllr} 
& & & & tonnes & $\%$ \\
\hline Perennial ryegrasses & $\ldots$ & $\ldots$ &. & $\ldots .$. & 9691 & 71 \\
Other ryegrasses . . . . & $\ldots$ & $\ldots$ & $\ldots$ & $\ldots$ & 2991 & 22 \\
Cocksfoot, timothy, prairie, dogstail .... & $\ldots . .$. & 914 & 7 \\
\hline
\end{tabular}

* From Seed Testing Station, MAF, 1978.

Perennials include Ruanui, Nui, Ariki and N.Z. Perennial Ryegrass. Other ryegrasses include Manawa, Paroa and Tama. N.Z. Perennial is certified on laboratory test only (up to $4 \%$ fluorescence under uv light) and is mainly from crops which have failed 
field inspection or have been entered too late for certification (D. J. Scott, pers. comm.) . It provides $27 \%$ of the perennial ryegrasses.

Certified seed is also an important export industry as shown in Table 2.

TABLE 2: CERTIFIED RYEGRASS SEED EXPORTED ANNUALLY* (Mean of 1973-77)

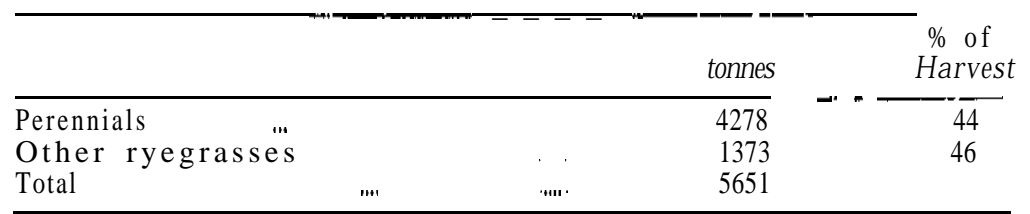

*From Seed Testing Station, MAF, 1978.

Forty-five percent of all ryegrass seed harvested annually is exported which represents a mean value of $\$ 3.2$ million of which \$2.4 million was from perennials.

In his Presidential Address to the New Zealand Grassland Association, Corkill (1958) noted: "As long ago as the eighties of last century it was known that there were differences in performance between strains of perennial ryegrass in New Zealand. But many years were to pass before the farmer could be assured of obtaining seed of the better strains." Dr Corkill traced the development of production of certified seeds in New Zealand, noting particularly the work of Sir Bruce Levy, Dr William Davies and J. W. Hadfield in 1928-30.

Lolium perenne developed from sowings made by the early settlers into distinct strains described by Corkill (1950a) as "true perennial strains" in permanent grassland regions such as Poverty Bay and Hawke's Bay and "short lived strains" in the arable regions of the South Island. By breeding with selected plants from the "true perennials" a "pedigree strain" was produced, superior to the best "old pasture" and uncertified strains in production, persistency and resistance to leaf rust (Table 3).

The utilization of these persistent, productive types in breeding programmes coupled with the initiation of a certified seed scheme was a major advance in making reliable plants available to the farmer.

\section{USE IN NEW ZEALAND AGRICULTURE}

Perennial ryegrasses are the basis of most permanent pasture sowings in New Zealand. In a survey of 157 seeds mixtures for 
TAELE 3: RELATIVE YIELD, PERSISTENCY AND LEAF RUST SUSCEPTIBILITy OF SOME RYEGRASSES AT PALMERSTON

$$
\text { NORTH }
$$

(Corkill, 1950a)

\begin{tabular}{lcccc}
\hline & $\begin{array}{c}\text { Relative } \\
\text { Yield }\end{array}$ & $\begin{array}{c}\text { \% Survival } \\
\text { in 2nd year }\end{array}$ & $\begin{array}{c}\text { \% } \\
\text { Plants with } \\
\text { Lea] Rust }\end{array}$ \\
\hline Pedigree & R & 100 & 98 & 9 \\
North Island “old pasture" & 89 & 94 & 72 \\
South Island "old & pasture" & 63 & 73 & 75 \\
\hline
\end{tabular}

the southern part of the North Island, Harris (1968) examined the occurrence of Ruanui, Manawa, Ariki and Paroa. Ruanui was contained in 79.5\%, Manawa in $60.3 \%$ and Ariki in $47.5 \%$ of the mixtures.

The importance of different ryegrass cultivars in some districts of the country is expressed by data derived from sales by one of the major seed merchants (Table 4).

TABLE 4: DISTRICT RETAIL SALES OF RYEGRASS CULTIVARS $1977-8(\%)$

\begin{tabular}{lcrrrrr}
\hline & Ruanui & Nui & Ariki & M anawa & Paroa & Tama \\
\hline Waikato & 20.2 & 38.1 & 18.5 & 12.0 & 6.7 & 4.5 \\
Manawatu & 52.4 & 21.6 & 7.8 & 7.1 & 6.5 & 4.6 \\
Canterbury & 43.1 & 12.3 & 4.0 & 12.5 & 17.0 & 11.1 \\
Southland & 56.4 & 2.8 & 10.1 & 14.6 & 9.6 & 6.5 \\
North Island & 46.0 & 22.4 & 8.9 & 9.2 & 6.2 & 7.3 \\
South Island & 51.5 & 7.6 & 6.5 & 13.8 & 11.1 & 9.5 \\
& & & & & & \\
New Zealand & 49.9 & 11.8 & 7.2 & 12.5 & 9.7 & 8.9 \\
N.Z. 1976-7 & 53.7 & 6.6 & 8.2 & 13.3 & 8.8 & 9.4 \\
N.Z. 1975-6 & 54.2 & 2.4 & 10.0 & 13.0 & 9.4 & 11.0 \\
\hline
\end{tabular}

These data show some interesting regional trends which could reflect climate, farming patterns and presumably also the individual vendor's preference.

However, the results demonstrate the importance of Ruanui among the perennials, although the annual figures suggest an increase in the use of Nui at the expense of both Ruanui and Ariki. 


\section{UNCERTIFIED LINES}

Early comparisons of certified and uncertified lines were made by Corkill (1950b) over a range of pasture species including perennial ryegrass, Italian and Westerwolds ryegrasses, cocksfoot, timothy, and white and red clovers. Without exception, his data showed higher total production with better seasonal spread, better persistency and increased resistance to diseases in the certified cultivars.

More recently, Cumberland and Honore (1970) have compared the herbage yield of a local uncertified perennial ryegrass population Ellett", with Ariki and Ruanui in a 3-year mowing trial near Auckland. In the last two years of the trial there was little differcnce in total herbage production betwen the three pastures but ryegrass yields were markedly higher in Ellett than in Ariki which was itself superior to Ruanui.

The productions from Ellett, Ruanui and Nui have been compared under mowing at Grasslands Division, Kaikohe (B. M. Cooper, pers. comm.). Results for the first two years are presented in Table 5.

Nui was markedly superior to Ruanui and Ellett in the first year, but there was little difference beween the ryegrasses in the second year. This trial is continuing.

TABLE 5: HERBAGE YIELDS FROM THREE RYEGRASSES UNDER MOWING AT KAIKOHE (DM kg/ha)

(Sown autumn 1976)

\begin{tabular}{lccc}
\hline & Ellett & Ruanui & N ui \\
\cline { 2 - 3 } Winter & 2868 & 2852 & 2919 \\
Spring & 4977 & 5562 & 5390 \\
Summer & 4103 & 3878 & 4571 \\
Autumn & 2256 & 1336 & 2788 \\
\hline Year 1 & $14204 \mathrm{~b}$ & $13628 \mathrm{~b}$ & $15668 \mathrm{a}$ \\
\hline Winter & 3619 & 3009 & 3415 \\
Spring & 4809 & 4890 & 4525 \\
Summer & 760 & 813 & 815 \\
Autumn & 1709 & 1583 & 2043 \\
\hline Year 2 & $10897 \mathrm{a}$ & $10295 \mathrm{a}$ & $10798 \mathrm{a}$ \\
- - - & $25101 \mathrm{~b}$ & $23923 \mathrm{~b}$ & $26466 \mathrm{a}$ \\
\hline
\end{tabular}

"Formerly known as Mangere ryegrass which was originally produced by T. R. Ellett near Auckland by harvesting seed from 60 -year-old pastures used for dairying. 
Further information on the comparative performance as spaced plants of two local populations with Nui and Ruanui at Palmerston North is given in Table 6.

TABLE 6: RELATIVE SINGLE PLANT GROWTH SCORES

(Planted April 29, 1976)

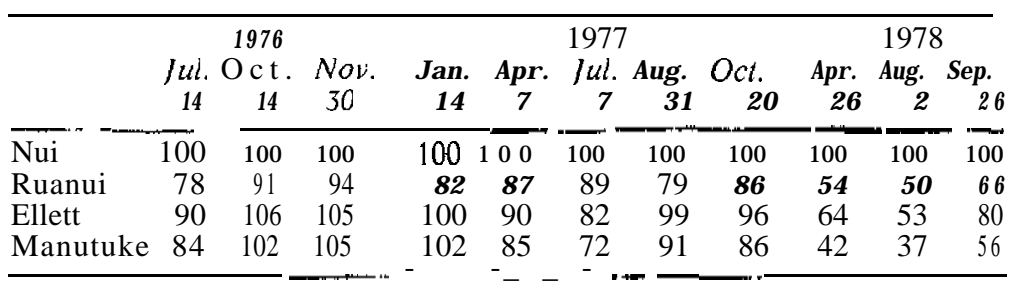

These relative scores show the general superiority of Nui, although in the first spring notes the two local populations are higher producing. Manutuke ryegrass is a seed collection from the Manutuke Research Station and is described as being old Poverty Bay ryegrass. In Canterbury, Vartha (1975) showed that a local population Smiths ryegrass gave similar annual and seasonal yields to Ruanui in a 3-year mowing experiment, while in a similar trial at Waimate McLeod (1974) found that Ellett gave higher ryegrass yields than Ruanui and Ariki.

\section{COMPARISONS WITH OVERSEAS CULTIVARS}

Cultivars obtained from overseas are often suggested as valuable for New Zealand agriculture, but generally they have been found to lack winter yield and persistency (Rumball, 1969). Initial evaluations of overseas material, and collections from within New Zealand, are almost invariably accomplished as spaced plants, in comparison with bred standards (Rumba11 and Armstrong, 1974).

In Table 7 one well-known cultivar from each of eight different countries is compared with Nui and Ariki, and all are relative to Ruanui at 100 . Each cultivar appeared in varying numbers of experiments conducted at different sites, and each relative score represents the mean of all seasonal growth scores at each site in the given number of experiments. Scorings were made by several different observers. It is of interest that one of the best overseas cultivars, Vigor, has been accepted for the New Zealand List of Aceptable Herbage Cultivars, as has S23 which ranks fourth overall amongst the overseas cultivars. These are both late flowering varieties and there are suggestions that because of continued 
PERENNIAL RYEGRASS CULTIVARS

TABLE 7: COMPARISON OF NEW ZEALAND AND OVERSEAS MATERIAL AS SPACED PLANTS

(Means of growth scores over 2 years relative to Ruanui) (Rumbal1 and Armstrong, 1974)

\begin{tabular}{llccccccc}
\hline Cultivar & Origin & $\begin{array}{c}\text { No. of } \\
\text { Expfs }\end{array}$ & Sites & Wint. & Spring & Sum. & A ut. & A nn. \\
\hline Ruanui & N.Z. & 28 & $12,3,5,5$ & 100 & 100 & 100 & 100 & 100 \\
Nui & N.Z. & 11 & $12,3,5$, & 158 & 139 & 160 & 164 & 155 \\
Ariki & N.Z. & 13 & $1,2,3,5$ & 139 & 129 & 134 & 137 & 135 \\
Tasmanian & & & & & & & & \\
No. 1 $\quad$ Australia & 6 & 1,3 & 88 & 81 & 70 & 67 & 77 \\
S23 & U.K. & 13 & $1,2,3,4$ & 60 & 67 & 57 & 55 & 60 \\
Vigor & Belgium & 12 & $1,2,3,4$ & 80 & 79 & 73 & 77 & 77 \\
Premiere & France & 4 & 1,3 & 65 & 44 & 41 & 43 & 48 \\
Viris & Sweden & 5 & $1,2,3$ & 62 & 40 & 43 & 37 & 46 \\
Argo & Poland & 3 & 2,3 & 63 & 60 & 48 & 26 & 49 \\
Otofte D e n m a r k & 4 & 1.3 & 87 & 46 & 44 & 41 & 55 \\
Barenza & Netherlands & 7 & 2,3 & 68 & 69 & 79 & 56 & 68 \\
\hline
\end{tabular}

Key to sites: 1 Gore, 2 Lincoln, 3 Palmerston North, 4 Kaikohe, 5 Wairarapa, 6 Hawke's Bay.

leafiness they would be valuable in southern areas for lamb meat production. No direct data are available to support this contention although at Palmerston North in October/November it has been noted that the late flowering Vigor had a higher legume content and a higher leaf: stem ratio in grazed plots than Nui or Ruanui.

Six ryegrass cultivars-Ariki, Manawa, Ruanui, Tasmanian No. 1, S23, S24-were compared under mowing for 3 years at Palmerston North (L. W. Gorman, pers. comm.) . Annual yields of sown grass were in the range 8400 to $11100 \mathrm{~kg} \mathrm{DM} / \mathrm{ha}$ with Ariki and Manawa superior to all others, and Ruanui more productive than Tasmanian No. 1. S24 and S23 were lower yielding than all other cultivars. There were marked seasonal differences, with Ariki yielding well at all times especially in summer and autumn, Manawa notably winter active and Tasmanian No. 1 good in spring and early summer but poor in autumn. S24 produced poorly in each season and S23 was a good summer producer. However, Vartha (1977) found that S23 was considerably inferior to Ruanui in summer on a medium heavy soil in Canterbury.

In South Canterbury, McLeod (1974) compared several overseas perennial ryegrasses (diploids and tetraploids) with Ruanui and Ariki under mowing. He noted only two advantages from imported material: tetraploids were faster establishing than the New Zealand diploids, and diploids had superior mid- to late summer growth. He pointed out, however, that late maturity and 
the ability to grow in January/February would be usually restricted in that environment by dry weather.

\section{COMPARISONS OF NEW ZEALAND CULTIVARS}

\section{ARIKI}

Early comparative assessments of Ariki and Ruanui were reported by Barclay (1963) who described the characteristics of Ariki as well as presenting experimental evidence on its perforformance. He noted that it was persistent and had a wide seasonal spread of production, intermediate between Ruanui and Manawa at most times of the year but superior to both in summer.

Bascand (1963), in summarizing some 60 farm grazing trials, concluded that there was clear evidence of persistency with a quicker recovery after drought or grazing than Ruanui. He noted that annual and seasonal yields of both total herbage and ryegrass component were better than Ruanui or Manawa and that its ability to compete with weeds was impressive. Ariki tended to be inferior to Ruanui on "infertile" soils.

TABLE 8: SEASONAL YIELDS OF THREE RYEGRASS CULTIVARS ( $\mathrm{kg} \mathrm{DM} / \mathrm{ha}$ )

(Harris et al., 1973)

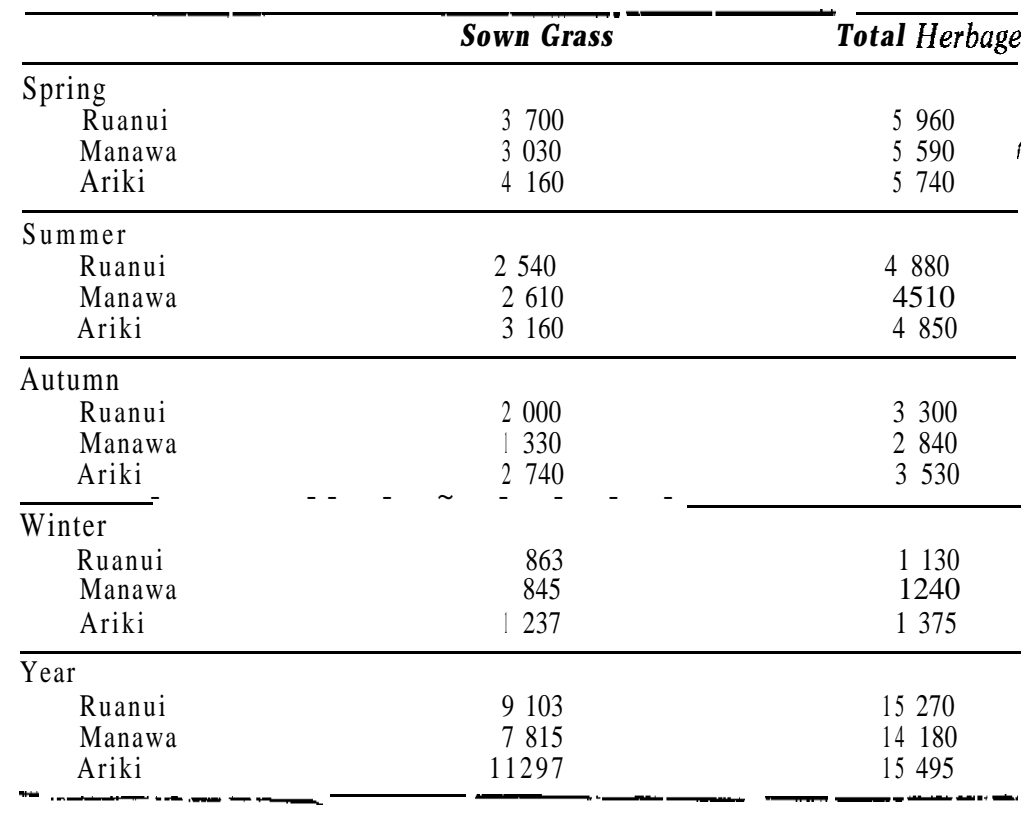


In Southland, herbage production from eight mixtures of a grass with "Grasslands Huia" white clover has been described by Harris et al. (1973). Mean herbage yields over 2 years for three reygrass pastures grazed from $8-10 \mathrm{~cm}$ to $2 \mathrm{~cm}$ are presented in Table 8.

In spring, Ariki gave higher grass yields, although its total herbage production was not different from Ruanui or Manawa.

There was a similar trend in summer when Ariki produced more grass but total herbage from the mixtures was not different.

In autumn, differences were spparent between all cultivars in both sown grass and total herbage, with Ariki the highest producer.

In winter, Ariki again produced more grass but there were similar total herbage yields. In all seasons except autumn, white clover growth tended to compensate to produce similar total yields. The more vigorous Ariki sward contained 20\% white clover on in annual basis compared with $26 \%$ for Manawa and Ruanui. This higher percentage white clover did not compensate for the poor productivity of Manawa caused by a deterioration in density of the sward following the first summer of a 3-year experimental period.

In a series of experiments in Southland, Harris and Johnston (1967; 1973) showed higher liveweight gains in lambs grazing Ariki pastures than Ruanui pastures in the autumn, although no differences were shown during the spring. This advantage in animal production was attributed to greater herbage yields in the Ariki pastures, but the $15 \%$ higher feeding value of Ariki over Ruanui (Lancashire and Ulyatt, 1975) may also have been a factor.

Nur

Nui is the most recent perennial ryegrass cultivar released in New Zealand and has been described by Armstrong (1977). He concluded that it is a true perennial, able to withstand grazing pressures, especially under dry conditions. This ability to persist through dry conditions was confirmed by Ritchie (1975), who also observed in a number of trials that Nui gave earlier and more reliable autumn production than Ruanui or Ariki. He commented that this improved summer and autumn production often led to better annual yield but that there was some evidence that Nui was more susceptible to Argentine stem weevil than Ruanui. Yields of Nui and white clover in the Waikato were shown by 
Baars et al. (1975) to be $11 \%$ higher than Ruanui based pastures and comparable with Ruanui and paspalum with white clover. They concluded that a promising pasture mixture would be Nui with paspalum and white clover.

A series of cutting experiments'at four sites - Kaikohe, Palm. erston North, Lincoln and Gore (Harris et al., 1977) compared Ariki, Manawa, Nui and G4708 (a tetraploid hybrid ryegrass). Over the wide range of climatic conditions annual herbage production from Nui (up to $16500 \mathrm{~kg} \mathrm{DM} / \mathrm{ha}$ ) was superior at all sites and was on average $13 \%$ higher than the next highest producer, G4708. Spring, summer and autumn yields of Nui were generally higher than for the other cultivars.

Under sheep grazing at Palmerston North, Nui has consistently established faster than other perennial ryegrass cultivars when sown with Huia white clover. Relative ryegrass yields at the first grazing in May from a sowing in March 1976 were Nui 100, Ruanui 84 and Vigor 35. The superiority of Nui during the establishment period was also illustrated by the botanical composition in October (Table 9).

TABLE 9: BOTANICAL COMPOSITION IN OCTOBER $1976(\%)$ (Sown April 13, 1976)

\begin{tabular}{lccc}
\hline & Ryegrass & Huia & Poa \\
\hline Nui & 94 & 4 & $!$ \\
Ruanui & 89 & 6 & 5 \\
Vigor & 72 & 15 & 9 \\
\hline
\end{tabular}

The greater persistency of Nui in these pastures following the 1978 drought was shown by the ryegrass composition in mid-July 1978 -Nui 87\%, Ruanui and Vigor $25 \%$,

In a comparison under dairy cow grazing in the Waikato, Baars and McLeod (1976) found that Nui/white clover outproduced Ruanui pastures by $12 \%$ over an 18 -month measurement period. Overall, Nui gave $30 \%$ more ryegrass production than Ruanui with least difference in spring and the greatest in autumn and winter.

The effect of grazing or cutting frequency on the yield of different herbage species and cultivars has been widely reported (Brougham, 1960; Harris et al., 1977; Boswell, 1977; Lancashire and Harris, 1978).

Under sheep grazing in Southland, Nui based pastures outyielded Ariki and Ruanui based pastures (Table 10), although 
TABLE 10: SEASONAL YIELDS OF THREE RYEGRASS/HUIA WHITE CLOVER PASTURES AT GORE (DM kg/ha) (Mean of 3 years)

\begin{tabular}{|c|c|c|c|c|c|c|}
\hline - & & Spring & Summer & A utumn & Winter & Y ear \\
\hline \multicolumn{7}{|c|}{ Sown grass } \\
\hline Nui & 3 & 900 & 3490 & 2215 & 795 & 10410 \\
\hline Ruanui & 3 & 300 & 2590 & 1520 & 540 & 7950 \\
\hline Ariki & 3 & 660 & 3310 & 1565 & 715 & 9260 \\
\hline $\mathrm{d} 05$ & & 250 & 330 & 130 & 60 & 520 \\
\hline \multicolumn{7}{|c|}{ Total herbage } \\
\hline Nui . & 5 & 550 & 5830 & 2835 & 956 & 15180 \\
\hline Ruanui & 5 & 800 & 5750 & 2410 & 812 & 14780 \\
\hline Ariki & 5 & 570 & 5730 & 2370 & 931 & 14580 \\
\hline $\mathrm{d} 05$ & & n.s. & $\mathrm{n}, \mathrm{s}$ & 170 & 90 & 480 \\
\hline
\end{tabular}

the marked advantage in ryegrass production in the Nui sward was offset to some extent by higher yields of white clover in Ariki $(30 \%)$ and Ruanui $(36 \%)$, cf. Nui $25 \%$.

There was also evidence in this trial that Ariki and Nui responded better than Ruanui to less frequent grazing in summer and winter, while in dryland conditions in Canterbury (K. R. Brown, pers. comm.) Nui was no better than Ruanui under frequent and intensive grazing. In official trials in the U.K., Nui performed better relative to the control cultivar Cropper under a 4-cut system than a 9-cut system (National List Trial Reports, 1979)

\section{CONCLUSION}

There appears to be scope for increased animal productivity from pastures when the total feed rquirement of animals at present stocking rates are compared with pasture yields from grazing experiments. The potential for yield from the cultivars Ariki and Nui will only be exploited if grazing management systems allow appropriate spelling intervals between defoliations and where soil nitrogen status is relatively high. In general, Ruanui appears more tolerant of poor management-e.g., set-stocking and low soil "fertility" (Bascand, 1963) -but cannot respond as well as the newer cultivars to improved management or increased nitrogen supply (Brock and Hoglund, 1979; W. F. Hunt, pers. comm.) .

Future improvements in perennial ryegrasses may come from the production of regional lines, improved resistance to pests and diseases, and selections for high and low "fertility" conditions and 
for different grazing managements. Farmer optimism in the future production of new cultivars is expressed by Miller (1978) who forecasts that "more and better strains of ryegrass and compatible clovers will be developed." In particular, he stresses the need for more efficient techniques in order to fully utilize the growth potential of these grasses.

\section{ACKNOWLEDGEMENT}

Wrightson NMA, Gore, for information on retail seed sales.

\section{REFERENCES}

Armstrong, C. S., 1977. N.Z. /l exp. Agric., 5: 381-4.

Baars, I. A.; McLeod, C. C., 1976. A. Rep. Res. Div. MAF: 138-9. Baars, J. A.; Cunnane, T.; Glass, S., 1975. Proc. Ruakura Fmrs' Conf::

Barclay, P. C., 1963. Proc, N.Z. Grassld Ass., 25: 128-37.

Bascand, L. D., 1963. Ibid.: 137-44.

Boswell, C. C.; 1977. N.Z. Il exp. Agric., 5: 403-6.

Brock, J. L.; Hoglund, J. H., 1979. N.Z. $/ l$ agric. Res. (in press).

Brougham. R. W., 1960. N.Z. /l agric. Res., 3: 125-36.

Corkill, L., 1950a. Grasslds Bull. No. 3. Grasslands Division, DSIR, Palmerston North.

Wellington.

1958. Proc. N.Z. Grassid Ass., 20: 1-10.

Cumberland, G. L. B.; Honore, E. N., 1970. N.Z. agric. Sci., 4: 21-4.

Harris, A. J.; Johnston, J. M., 1967. N.Z. Il agric. Res., 10: 350-6. 1973. N.Z. $I l$ exp. Agric., 1: 6-10.

Harris, A. J.; Brown, K. R.; Turner, J. D.; Johnston, J. M.; Ryan, D. L.; Hickey, M. J., 1973. Ibid., 1: 139-63.

Harris, A. J.; Boyd, A. F.; Anderson, L. B.; Vartha, E. W.; Ryan, D. L., 1977. Ibid., 5: 391-5.

Harris, W., 1968. Proc. N.z. Grassld Ass., 30: 143-53.

Lancashire, J. A.; Ulyatt, M. J., 1975. N.Z. $/ l$ agric. Res., 18: 97-100.

Lancashire, J. A.; Harris, A. J., 1978. Proc. N.Z. Grassid Ass., 39(1): 10820.

McLeod, C. C., 1974. Ibid., 35 (2): 21 1-8.

Miller, C. C., 1978. Ibid., 40: 145-51.

National List Trial Reports, 1979. PI. Var. Seeds Gaz. No, 168: 87.

Ritchie, I, M., 1975. A. Rep. Res. Div. MAF: 144-5.

Rumball, W., 1969. Proc. N.Z. Grassid Ass., 31: 35-42.

Rumball, W.; Armstrong, C. S., 1974. Ibid., 36(1) : 97-104.

Seed Testing Station, MAF, 1978. Certified Seed Production Statistics, 1978. MAF, Palmerston North.

Statistics Department, 1976. Agricultural Statistics, 1972-73. Govt. Printer, Wellington.

Vartha, E. W., 1975. N.Z. /l exp. Agric., 3: 319-23.

1977. Ibid.. 5: $137-41$. 